\title{
Defense of what? ${ }^{1}$
}

\author{
ROBERT C. ANGELL
}

Department of Sociology, The University of Michigan

In times so fraught with peril to all mankind as ours, it is well to re-examine fundamental assumptions. Most Americans are convinced that they know quite well what we are defending. But have they thought the question through? Have they taken into account the new context within which it is posed today?

When any of us asks himself, "What are we defending?" the first thing that springs to mind is the national territory. This reaction doubtless goes back to countless generations of agricultural forebears who cherished their acres almost as much as they cherished their children. Can there be anything more obvious than that no one has the right to wrest from us the land from which we draw our sustenance? Although the attachment to territory is still very strong, especially locally or regionally, it is perhaps less so than it once was. The decline in the farm population and the movement of urban families from one location to another, by weakening our attachment to real estate, have perhaps led us to cherish less the national territory. Even though a Californian would certainly bridle at any suggestion that a border area of his state be ceded to Mexico, would he object if Texas were asked to make a similar sacri-

\footnotetext{
1 This paper is a shortened and considerably revised version of one of the Shambaugh Lectures on National Defense at the State University of Iowa. It was given January 11, 1961.
}

fice? We were able to bring ourselves to move the natives of the Bikini atoll to a new island. If there were some good reason why Americans and Canadians should trade islands in the St. Lawrence or swap equal tracts in Montana and Manitoba (thus creating salients across the 49 th parallel), would we really mind very much, provided the families were resettled equitably?

Although territory certainly remains an element of what we are defending, it seems likely that this is so mainly because land is closely associated with the web of social life that has been woven on it. It has become symbolic of that web. I remember the words of a French woman, married to an American officer at the close of World War $I$ and long resident in this country: "I cannot bear to think of being buried anywhere but in the soil of France." What I think she was saying was that she could not bear to be cut off permanently from her French cultural roots. And so it is for all who have grown up in a particular way of life and learned to love it.

But precisely what do we mean when we say "the American way of life"? Of all the forms and patterns of our daily round, which are the essential ones, which the inconsequential? Or, to invert the order, which could we let go without a tear, which would we fight to defend? 
In another place ${ }^{2}$ I have suggested that there are three classes of constants in American life-constants from conviction, from external pressure, and from utility. It is not in point to discuss the last two classes; it is the constants from conviction that I believe exemplify the essentials of our way of life and therefore stand for what we are defending.

The constants from conviction are the precipitations of such typically American common values as equal opportunity, humanitarianism, and technological progress. They are perhaps best described by the term institutions. The frame of our government, with its democratic control and its checks and balances, is perhaps most central. Our free system of public education is only a little less so. Nor can we conceive the good life without monogamous families with an equalitarian relation between husband and wife and a recognition of the moral worth of children. There is no established church, but our system fully protects the right of citizens to found churches and worship according to their convictions. In the economy, it is not altogether clear what deserves to be called institutional and what does not. Laissez-faire capitalism has already been greatly altered and yet we are far from being socialists. Perhaps on this matter we may say that we want to work out the problems in our own way, and that we are defending our right to do so.

There are three situations in which defense of our institutions takes place: against foreigners, against unlawful attacks of our fellow citizens, and against their lawful attacks. Our defense takes on a different character in each of these because of

2 "The Structure of United States Society, and Politics," (Lasswell and Cleveland, 1962, ch. 15). the different relation each bears to one of the central features of our system, our civil liberties.

The democratic theory holds that public discussion will successfully separate the chaff of unsound ideas from the wheat of sound ones. But only those are entitled to participate in the winnowing process who are responsible members of the body politic. Those upon whom proposed changes will not bear have no inherent right to propose them. When a foreigner attacks our institutions, therefore, we tend to wrap the flag around our whole system. Like all groups under external pressure, we tend to close ranks and present a monolithic front of opposition.

Our defense against unlawful attacks of our fellow citizens is vigorous, but for a different reason. The attackers are thought to have surrendered any rights to a hearing for their reforms because of the illegitimacy of their methods. Since they are seen as people biting the hand that feeds them, the defense is likely to be rancorous in the extreme. And this is true even when the attackers are clearly not minions of a foreign government. The Industrial Workers of the World, a native syndicalist movement in the first two decades of this century that stood for the violent overthrow of capitalism, was sharply curbed by the federal government and by many state laws.

Finally, lawful attacks by fellow citizens are met by a more temperate defense. Since at least the better educated strata of our people understand that our civil liberties are a part of the life we are defending, they acknowledge the right of others to criticize even constants by conviction and to try to change them. The attack is within the rules of the democratic game and the defense must be similarly so.

Until the outbreak of World War II, very 
few Americans thought we were defending anything outside the United States. The isolationism that came naturally from the protection of two great oceans had been broken only briefly by Theodore Roosevelt's essay at imperialism and Woodrow Wilson's dream of the United States as a leader in the League of Nations. The sudden shift in attitude as Hitler began to overrun Europe was perhaps most dramatically embodied in the later career of Senator Vandenberg of Michigan. A former isolationist, he suddenly saw that, whether we liked it or not, we had joined the world and must behave like an adult member of it.

So far we have discussed what we are defending only in terms of our national territory and the way of life built upon it. It is obvious that today we do not defend only what lies within this compass. There are two wider circles of life that we defend. One of them is best expressed by the phrase "our bloc." The other does not have such a convenient identity. It may be described by the awkward phrase: "a world order we can live with." I will take up each of these in turn.

Even if we limit our bloc to the nations with which we have treaties that will bring us to their aid if they are attacked, it is apparent that what we are defending is far from a homogeneous group of societies. As a matter of fact, our allies fall into two quite distinct categories. One of these consists of nations with whom we feel a real affinity because their way of life is very like ours. Culturally, we have much in common with them. In this category are the members of the British Commonwealth that are members of the North Atlantic Treaty Organization or the Southeast Asia Treaty Organization-Canada, Britain, Australia, and New Zealand; democratic Euro- pean nations-Iceland, Norway, Denmark, West Germany, Belgium, France, Italy, and Greece; and another member of the Southeast Asia Treaty Organization, the Philippines. The second category contains a much more varied group of nations, some of which are strange bedfellows. South Korea, Turkey, Thailand, and Iran are not fully democratic in their political processes, but Pakistan, Portugal, Spain, and Nationalist China are either outright dictatorships or one-party states. Japan is more acceptable to us politically, but its culture is very different.

When we ask how it happens that the second group of nations is in our bloc, the reason is unmistakable: they represent a crucial resource in the struggle against international Communism. When including them in what we are defending we have not demanded that their central values and institutions be closely similar to ours. We have been willing to throw the cloak of our protection around them for the simple reason that we wish to contain Communism within its present borders. In order to accomplish this result we are willing to overlook profound cultural differences. Some have argued that we should not collaborate with countries like Portugal and Spain, but this objection has carried little weight with our policy-makers.

In passing, it is interesting to note that most of the nations of the second group are very distant from the United States and very close to the Soviet-Chinese heartland. This gives a vivid demonstration of the radically increased power of modern weapons. For the first time in history, states feel that they can effectively deter attacks upon allies that live closer to the potential enemy than to themselves.

If by some magic of diplomacy the threat of war between the Soviet-Chinese coali- 
tion and ourselves were to be removed, it is a sure prediction that we would be less inclined to remain allied to nations in the second category than in the first. The first group represents both principles of social organization that we believe in and religious traditions with which we have much in common. One or the other of these ties is lacking for all the nations of the second group.

The heterogeneity of the bloc proves clearly that we can live, if need be, with those of quite different conceptions of the good life from ours. This fact becomes very significant when we pass to the examination of the third circle that I mentioned -the world order we can live with.

It is a great error to assume, as many do, that the two great blocs of our time operate in a sort of vacuum or perhaps float in a colorless medium. Actually, an elaborate web of relationships is being woven among the peoples of the world and the two blocs are entangled in the web. We cannot be content merely to have a strong nation and a strong bloc. We must also be concerned with the nature of the enveloping web. We must identify the texture that will be satisfactory to us, and try to see that it comes into being. To change the figure, there is live and growing tissue around us, interstitial tissue if you will, which is spreading and becoming stronger every year.

This way of looking at the matter is in sharp contrast to the point of view that underlies a currently important approach to international affairs, the theory of games. This theory assumes that two great nations, say the United States and the Soviet Union, confront one another like two chess players. When it is one player's turn to make a move he considers the alternatives open to him, imagines what will be his opponent's retort to each of these alterna- tives, and rationally chooses the move that will be most likely to yield him the greatest "payoff" against maximally rational play by his opponent. Chess is a "zero-sum" game; that is, what one player wins the other one loses. But in real life, there are games in which both sides may lose, or win. For instance, two starving men would be foolish to fight over a few vegetables on the near side of a high wall when, by helping each other, they could climb the wall and reach a much larger store of food known to be on the other side. Such "plus-plus" payoffs would, if they could be found, make international peace easier to attain.

The theory of games is being imaginatively exploited by those who are studying military and diplomatic strategies. There can be no quarrel with this, since the game model is near enough to the reality of international struggle to make it a profitable one. It has, however, one serious weakness. It assumes that the game takes place in an essentially stable environment. Certain geographical conditions are given; natural resources are available to the contestants in specified amounts; manpower and technological equipment on both sides are constant or at least changing proportionately; the influence of other nations remains the same; and whatever rules are recognized by the two parties continue in force. In short, given this constancy of the milieu, the response of each party is only to the prior move of the other. It is a struggle between contestants for whom only the choices of the other are problematical. All else is assumed to be constant.

If one thinks exclusively in terms of the theory of games, the only way to get the optimum payoff is to make the most rational moves; that is, to make the right disposition of the forces at one's disposal. Since the whole context within which the 
game is being played is taken as given, the possibility that the most rational thing to do is to change the context is not likely to occur to anyone. But the context is in fact changing all the time whether the parties will it or not. Especially in our day is the interstitial tissue that we mentioned building up. To see to it that it is of one kind rather than another may in the long run be the most profitable of all aims and undertakings. Yet this is a concern that preoccupation with the theory of games is not likely to foster.

In reality, the theory of games model is essentially static. Although the players are making new moves and even developing new strategies as the game progresses, the game itself is governed by the same old rules. The patterned context within which the players exercise their rationality does not change. We need a more dynamic model of international relations in our day. Perhaps the relations within a cluster of cities like Albany, Troy, and Schenectady furnish one. Here we get the picture of units that were originally free to exercise choice among a wide variety of alternatives finding themselves increasingly parts of a wider web of life, so that their actions become more and more functions of that wider organization and less and less functions of their discrete orientations.

In order that there may be no mistake about what I am saying, let me put it baldly. We are going to be more and more enmeshed in social organization of worldwide scope. The nature of that organization will be fateful for our own way of life. It will affect the meaning of existence for our citizens. It behooves us therefore to be vitally concerned about its nature as it develops. We must try to fix upon clear preferences for its characteristics, preferences that reflect the feasible as well as the desirable. Since much of the web that we will prefer has not yet been woven we shall be defending, in part at least, not an actuality but a vision.

It would be only natural to visualize this world that we can live with as an extension of our own society. But in this direction lies frustration. There are many nations that do not admire our way of life and have no intention of acquiescing in making the world a blown-up facsimile of this country. The interstitial tissue which will gradually develop will reflect the very small common denominator that there is in the various cultures of the world. Many principles that we believe in ardently will not be expressed in that tissue. They will, as it were, have been compromised out.

In view of this situation the only feasible course is to make minimum demands upon the world order, not the maximum ones that politicians, backed by superpatriots, make in the heat of international controversies or presidential elections. We must stop thinking, to paraphrase an oft-quoted remark, that what is good for the United States is good for the world. To take a less imperialistic view requires that we distinguish sharply between our own system of life and the world's system. Perhaps our trouble is that we leapt too quickly from isolationism to world-mindedness. In making the jump, we hardly realized that we were operating at a new level to which many of our traditional practices and values were unsuited. We must never cease being concemed about the nature of the growing intersocietal tissue, but our concern should take the form of insisting only upon that minimum of characteristics that will allow us and others like us to live happily and creatively on this shrunken globe.

Why is it so important to make only 
minimal demands? It is important because to be more ambitious is to invite hostility, increase tensions, and thwart our own hope to be a leader in constructing a viable world order. There are too many other peoples in the world with too many different orientations to life for us to monopolize the creative process of nourishing the interstitial tissue. We have lost much ground in the world already because of the blindness of American travelers to this truth. We can not afford to lose more.

It should not be so very difficult for us to take this stance. After all, we have admitted to our bloc nations with which we have little in common. If we can make minimum demands upon our allies, surely we can learn to make minimum demands upon the world order.

Of course what we do others must do also. Neither the Soviet Union, nor Communist China, nor India, nor Britain, nor France can make more than minimal demands. But if they all follow this course, there is real hope that the world can move along the tortuous path to a peaceful world order.

Now what precisely is meant by minimum American demands? What should we insist upon and what should we forgo? It seems to me that a minimal world-we-canlive-with would have two chief characteristics: (1) strengthened political means for preventing the conflicts among nations from erupting into war; and (2) an agreed program for fostering the development of more intersocietal linkages.

Under the first head fall the twin immediate necessities of movement toward disarmament and a strengthened United $\mathrm{Na}$ tions. It is obvious that nuclear deterrence, even if roughly balanced, is too risky a policy to live with any longer than is absolutely necessary. The United States Pro- gram for General and Complete Disarmament offered by President Kennedy to the United Nations Assembly on September 25, 1961 gives an admirable starting point for negotiating a disarmament agreement. This document voices our demand for a United Nations Peace Force to be built up as national armaments decline. In order to develop further other peace-keeping activities of the United Nations we should probably demand a revision of the Charter to make more realistic the representation in the Assembly. Some such scheme of weighted voting as is set forth in the ClarkSohn proposals would seem essential to give the great powers confidence in the proceedings of the organization. Continuing emphasis on the development of international law and expanded use of the International Court of Justice would be other features of a world we can live with. To this end, the repeal of our own Connally amendment is urgent.

The second characteristic of a minimal world-we-can-live-with, an agreed program for fostering more intersocietal linkages, is less discussed than are movements toward disarmament and the strengthening of the United Nations, but in the long run is equally important. The value differences in the world are so great, particularly between the Western bloc and the Communist bloc, that some means of lessening them must be found if we are ultimately to have a world rule of law. An enforceable legal system requires more threads of world-wide common value than presently exist. Such threads are most likely to appear as by-products of working together in common enterprises.

A cumulative process of increasing the number and strength of intersocietal linkages would have three main features: (1) the immediate intensive search for those 
areas in which national values are already sufficiently compatible to make feasible the broadening of existing international relationships, the enlargement of the functions of existing international organizations, and the establishment of new relations and organizations; (2) the full participation of all the key nations in the enlarged structural network thus brought into being; and (3) constant study of the changing attitudes and orientations resulting from this broadened participation to discover opportunities for extending the structural network still further.

The theory that lies back of this suggestion is simple: cooperation on tasks of mutual concern tends to breed trust. The more fully present possibilities for joint undertakings are exploited, the more trust will be created; and the more trust is created, the more it will be possible to set up new undertakings. Hence, the process is cumulative. Matters that are now so fraught with conflict as to be untouchable will gradually seem more amenable to collaboration as the climate changes because of the successful carrying through of mutually satisfactory undertakings in other fields.

If such a process is to succeed, it is obvious that two alternatives must be avoided. Too great hesitancy to embark upon joint enterprises will give a minimum basis for the development of trust, and hence the cumulation of confidence and of structure resulting therefrom will be inordinately slow. On the other hand, too great optimism about what can be done will breed failure and disillusion. The whole process would then be interrupted. These dangers are so great that it will take a combination of careful social science analysis and political wisdom to steer between Scylla and Charybdis.

The Specialized Agencies of the United
Nations already give impressive evidence of international cooperation. Important as these are, however, they have two limitations-they are universal and they are governmental. Conditions are almost certainly ripe for many joint ventures among some, but not all, countries, and with private persons and organizations as participants as well as governments.

Since the Cold War between the Communist bloc and the West is the greatest present threat to peace, structure that will bridge this value gap is what is most direly needed. Trade, travel, sport, scholarly contact, communication and exchange, and the interchange of musical and dramatic talent are the principal forms of cooperation today. Only one of these, scholarly contact, communication and exchange, gives real opportunity for persons from the two sides to work together over a period of time to achieve a joint result. The planning and holding of world congresses in scholarly fields gives great opportunities for friendly collaboration. The International Geophysical Year was the high water mark so far for cooperation in substantive research. It affords a model that might be followed in other fields with beneficial results.

If the theory here put forward is sound, the United States should be asking for a thorough canvass of the present possibilities of this kind. In the realm of science, there might be joint expeditions to Antarctica, joint investigation of the ocean deeps and of outer space, and joint meteorological projects beyond participation in the World Meteorological Organization. If it proved to be feasible, a joint attack on the world population problem, involving both biological and social science, would be of great importance.

Nothing is more global than questions of 
communication and transportation. At present, there is the setting of standards through the International Telecommunications Union and the International Civil Aviation Organization, but there may be further possibilities for joint action that might be considered. One in particular that has been suggested is the establishment by the United States and the Soviet Union of a network of communication satellites that will reflect messages back to any point on the earth and would be available for the use of all peoples.

A possibility, for which the time may not be ripe, is that the United States and the Soviet Union set up joint development projects in underdeveloped countries. Certainly nothing would be a more dramatic demonstration of their willingness to collaborate.

Disarmament is a special case because of its urgency. Although a joint study commission made up of natural and social scientists from both sides might seem to come under the head of risky adventures that might lead to disillusion, the tremendous benefits that might flow from such an enterprise may make it worth the risk. At all events, it should be carefully studied.

Although I have emphasized the need for the United States and the Soviet Union to take the initiative in building more intersocietal structure between the two blocs, there would of course be hope in new world-wide projects and organizations so long as both sides participated whole-heartedly in them. A United Nations university is one project of this type that has been repeatedly suggested. Since the ideological split between Western and Communist blocs would be the most difficult obstacle to be overcome in such an undertaking, Russian and American collaboration would be a sine qua non. In all cases there should be insistence that no new elements of structure be developed unless there is sufficient value consensus to make them good risks. Thus, all parties are protected against innovations that would be unacceptable to them.

If intersocietal linkages of the kinds we have discussed could be multiplied, both trust and greater ability to appreciate the values of the opposing group should increase. This should lead to opportunities for rational discussion of some of the really important problems on which the two blocs are divided. In international trade, there are the difficulties where private trading enterprises of the West meet the government monopolies of the Communist bloc; the tensions that arise from exchange controls; the disruptions caused by "dumping" of surpluses abroad; and the question of repaying foreign investors after properties have been nationalized. There are also many problems in the political field to which new approaches might become possible. Cross-national radio propaganda, including international slander, is one. Another is freedom of travel, seen from the viewpoint both of domestic restrictions on the travel of citizens abroad, and restrictions on incoming foreign nationals. Closely related is the freedom of expression and organization for those sympathetic to foreign ideologies.

If such problems could be rationally discussed, there would be a chance of finding principles for their solution to which all could agree. By this means the world rule of law would be brought nearer. Thus, if the immediate peace-keeping problems could be solved by political means, the long-run-value problems might be solved by jurisprudential means.

The answer to the question with which 
we started falls, then, into three parts. We are defending our own way of life, the bloc which is helping us defend that way of life, and a crescive world order in which there are effective peace-keeping agencies and wide support for processes leading toward the minimum of value consensus needed for a world rule of law.

REFERENCE

Lasswell, Harold D. and Cleveland, HarLAN (eds.). The Ethic of Power: the Interplay of Religion, Philosophy and Politics. New York: Harper \& Bros., 1962. 